\title{
HUBUNGAN PENGARUH PENOLONG KELAHIRAN \\ TERHADAP STATUS KELAHIRAN BAYI DENGAN \\ KONTROL VARIABEL CONFOUNDING \\ DI KABUPATEN BULELENG \\ (STUDI KASUS: PUSKESMAS SUKASADA II)
}

\author{
KADEK Novia DWiJAYANThi ${ }^{1}$, I GUSTi Ayu Made SRINAdi ${ }^{2}$, \\ Ni Luh Putu Suciptawati ${ }^{3}$
1,2,3 Jurusan Matematika FMIPA Universitas Udayana, Bukit Jimbaran-Bali e-mail: ${ }^{1}$ Novi_dj82@yahoo.com, ${ }^{2}$ srinadiigustiayumade@yahoo.co.id, 3 putusuciptawati@yahoo.co.id

\begin{abstract}
One indicator of the Human Development Index (HDI) is the Infant Mortality Rate (IMR). IMR is lower HDI showed a better area when compared with other regions for different values of the same indicators. This study aims to determine the relationship between the birth attendants birth status and confounding variables that affect the status of births in Buleleng regency, with Sukasada II health center located in District Sukasada - Buleleng regency as the location of the observed cases of infant mortality. Results of analysis using logistic regression showed that (1) birth attendants, (2) maternal age, and (3) income household heads have a real influence on the status of the baby's birth. Birth status with medical birth attendants have the opportunity to live 2,427 times compared with non-medical birth attendants with controlled variables maternal age and income of the family head.
\end{abstract}

Keywords: IPM, Infant Mortality, Sukasada district, Buleleng regency, Logistic Regression.

\section{Pendahuluan}

Kesehatan merupakan salah satu unsur penting dalam menentukan indeks pembangunan Manusia (IPM). Dengan kondisi kesehatan yang optimal masyarakat suatu daerah mempunyai kemampuan yang lebih besar untuk memenuhi kebutuhannya [2].

Angka kematian bayi merupakan salah satu indikator yang sangat penting dalam menentukan tingkat kesehatan masyarakat, karena dapat menggambarkan kesehatan penduduk secara umum. Tingginya angka kematian bayi tentu saja dipengaruhi oleh banyak faktor salah satunya adalah masih kurangnya kemampuan dan keterampilan penolong persalinan. Pemilihan penolong persalinan tidak hanya memengaruhi status kelahiran bayi namun memengaruhi angka harapan hidup ibu yang melakukan persalinan [2].

\footnotetext{
${ }^{1}$ Mahasiswa Jurusan Matematika FMIPA Universitas Udayana

${ }^{2,3}$ Staf Pengajar Jurusan Matematika FMIPA Universitas Udayana
} 
Selain penolong kelahiran, angka kematian bayi juga dikontrol oleh beberapa faktor yaitu umur ibu, pendidikan ibu, jenis kelamin bayi, jarak kelahiran, urutan kelahiran dan penghasilan keluarga.

Penelitian terdahulu yang dilakukan oleh Ardika [1] untuk mengetahui faktor apa saja yang memengaruhi angka kematian bayi diperoleh hasil bahwa umur ibu dan pengaruh bersama antara pendidikan ibu dan jenis kelamin bayi yang memengaruhi status kelahiran bayi. Penolong kelahiran tidak berpengaruh terhadap status kelahiran bayi. Sehingga terjadi ketidakseimbangan dalam menganalisis suatu kasus akibat adanya pengaruh variabel perancu atau confounding.

Tujuan dari penelitian ini adalah untuk mengetahui ada tidaknya pengaruh penolong kelahiran dan status kelahiran bayi di desa-desa yang berada di bawah tanggung jawab Puskesmas Sukasada II dan untuk mengetahui variabel perancu yang berpengaruh signifikan terhadap status kelahiran bayi di desa-desa yang berada di bawah tanggung jawab Puskesmas Sukasada II

Confounding adalah suatu variabel dalam penelitian yang tidak tercakup dalam hipotesis penelitian akan tetapi muncul dalam penelitian dan berpengaruh terhadap variabel tidak bebas. Pengaruhnya mencampuri atau berbaur dengan variabel bebas (Yasril dan Kasjono, [4]). Confounding adalah distorsi oleh variabel luar yang dapat mengacaukan atau mempengaruhi perhitungan pendugaan pengaruh variabel bebas terhadap suatu kasus (Murti, [3]).

Variabel confounding merupakan variabel luar yang pengaruhnya mencampuri pengaruh variabel penelitian terhadap suatu kasus (Yasril dan Kasjono, [4]). Ada tiga kriteria variabel confounding yaitu: (1) Merupakan faktor risiko bagi kasus yang diteliti; (2) Mempunyai hubungan dengan variabel bebas; dan (3) Bukan merupakan bentuk antara dalam hubungan kausal variabel bebas dan variabel tidak bebas.

Langkah-langkah Uji Confounding: (1) Melakukan seleksi variabel kandidat untuk masuk dalam model dengan cara analisis regresi logistik dengan p-Value $<0,25$; (2) Melakukan pemodelan regresi logistik ganda terhadap semua variabel kandidat; (3) Melakukan uji interaksi antara variabel tidak bebas dengan variabel bebas dan variabel confounding; (4) Melakukan uji confounder dengan menghitung selisih OR jika > 10\% maka variabel tersebut merupakan variabel confounding; (5) Pemodelan akhir dan interpretasi model (Yasril dan Kasjono,[4]).

\section{Metode Penelitian}

Data yang digunakan adalah data ibu rumah tangga yang pernah melahirkan di desa-desa yang berada di bawah tanggung jawab Puskesmas Sukasada II kecamatan Sukasada Kabupaten Buleleng, dengan sampel penelitian sebanyak 82 orang. 
Status kelahiran bayi (Y) merupakan variabel respon yang dikategorikan menjadi dua, yaitu status kelahiran bayi hidup dan status kelahiran bayi meninggal. Variabel bebas terdiri dari penolong kelahiran $\left(X_{1}\right)$, Umur Ibu $\left(X_{2}\right)$, Jenis Kelamin Bayi $\left(X_{3}\right)$, dan Jarak Kelahiran Bayi $\left(X_{4}\right)$. Variabel confounder terdiri dari Pendidikan Ibu $\left(Z_{1}\right)$, Penghasilan Keluarga $\left(Z_{2}\right)$, dan Urutan Kelahiran $\left(Z_{3}\right)$. Selanjutnya melakukan proses langkah-langkah uji confounding untuk melakukan analisis penelitian

\section{Hasil dan Pembahasan}

Analisis regresi berganda dalam penelitian bertujuan untuk menganalisis hubungan antara variabel bebas dan beberapa variabel confounding terhadap variabel status kelahiran bayi. Analisis regresi yang digunakan adalah analisis regresi logistik ganda dengan variabel kandidat yang masuk dalam model adalah variabel bebas dan variabel confounding dengan nilai p-Value $<0,25$. Berdasarkan analisis ini diperoleh variabel kandidat yang masuk dalam model adalah variabel penolong kelahiran (p-Value $=0,000<0,25)$, umur ibu (p-Value $=0,187<0,25)$, pendidikan ibu (p-Value $=0,001<0,25)$ dan penghasilan keluarga $(\mathrm{p}$-Value $=$ $0,003<0,25)$.

Dari hasil analisis tersebut kemudian dilakukan analisis regresi logistik ganda. Variabel yang masuk dalam model regresi logistik adalah variabel yang mempunyai p-Value kurang dari 0,05. Hasil regresi logistik ganda diperoleh variabel penolong kelahiran ( $\mathrm{p}$-Value $=0,000<0,05)$, umur ibu $(\mathrm{p}$-Value $=0,013$ $<0,05)$ dan penghasilan keluarga $(\mathrm{p}$-Value $=0,03<0,05)$ yang masuk ke dalam model.

Kemudian dilakukan pemeriksaan kemungkinan adanya interaksi antar variabel bebas dan confounding yaitu antara penolong kelahiran dengan penghasilan keluarga dan antara umur ibu dengan penghasilan keluarga. Dari analisis tersebut tidak terjadi interaksi antara variabel bebas dan variabel confounding.

Selanjutnya dilakukan pemeriksaan confounding yaitu dengan mengevaluasi variabel penghasilan keluarga yang diduga sebagai variabel confounding dengan membandingkan nilai OR variabel penolong kelahiran dan umur ibu dengan atau tanpa variabel penghasilan keluarga. Setelah dilakukan analisis diperoleh nilai OR penolong kelahiran sebesar 19,0\% > $10 \%$ dan nilai OR umur ibu sebesar 10\% > $10 \%$ maka variabel penghasilan kepala keluarga merupakan variabel confounding, sehingga diperoleh model regresi logistik adalah:

Log p (Status Kelahiran $)=-3,169-3,877($ Penolong kelahiran $)+0,142($ Umur Ibu) + 0,375 (Penghasilan Keluarga)

Menyatakan bahwa ibu yang melahirkan dengan penolong kelahiran medis menurunkan risiko untuk status kelahiran meninggal sebesar 0,021 kali 
dibandingkan penolong kelahiran nonmedis setelah dikontrol variabel penghasilan keluarga.

\section{Kesimpulan}

Kesimpulan yang dapat diambil berdasarkan hasil analisis dan pembahasan yang dilakukan pada bab sebelumnya adalah status kelahiran bayi dipengaruhi oleh penolong kelahiran, Umur ibu dan penghasilan kepala keluarga.

Model Regresi Logistik Ganda yang diperoleh dari pembahasan tersebut yaitu:

Log p ( Status Kelahiran ) = -3,169 - 3,877 ( Penolong kelahiran ) + 0,142 Umur Ibu ) + 0,375 ( Penghasilan Keluarga )

Dari model yang diperoleh, dapat dijelaskan bahwa ibu yang melahirkan dengan penolong kelahiran medis menurunkan risiko untuk status kelahiran meninggal sebesar 0,021 kali dibandingkan dengan penolong kelahiran nonmedis setelah dikontrol variabel penghasilan kepala keluarga.

\section{Daftar Pustaka}

[1] Ardika, I Gusti Ngurah. 2011 . Faktor-Faktor yang Mempengaruhi Kematian Bayi di Kabupaten Buleleng . Universitas Udayana

[2] Dinas Kesehatan [Dikes] Kabupaten Buleleng. 2009 . Profil Kesehatan Kabupaten Buleleng Tahun 2008. Dikes Kabupaten Buleleng. Singaraja.

[3] Murti, Bhisma. 2003. Prinsip dan Metode Riset Epidemiologi. Gadjah Mada University Press, Yogyakarta

[4] Yasril dan Kasjono.2008. Analisis Multivariat. Mitra Cendikia Press, Yogyakarta 